\title{
NEW MEDIA TECHNOLOGIES, DIGITAL SHARING, AND THE NEOLIBERAL ECONOMY
}

\author{
Elvira Nica ${ }^{1, a, *}$, Loren Taylor ${ }^{2, b}$ \\ ${ }^{1}$ Faculty of Administration and Public Management, Bucharest University of Economic Studies, Piata \\ Romana 6, Bucharest 010374, Romania \\ ${ }^{2}$ Latin America Center for Cognitive Economics, IISHSS, 30-18 50 ${ }^{\text {th }}$ Street, Woodside, New York \\ City, 11377, United States \\ aelvira.nica.2015@gmail.com, btaylor@aa-er.org \\ *Corresponding author
}

Cite as: Nica, E., Taylor, L. (2017). New media technologies, digital sharing, and the neoliberal economy, Ekonomicko-manazerske spektrum, 11(2), 103-110.

Available at: dx.doi.org/10.26552/ems.2017.2.103-110

\begin{abstract}
We rely on Sundararajan (2016) to prove that the sharing economy is the present stage of a constant progress of the economy and society that is influenced to some extent by digital technologies. The latter take individuals back to recognizable sharing conducts, selfemployment, and types of community-based network that survived before now: an enhanced type of something recognizable should gain boundless acceptance swiftly and have superior economic consequence than the creation of completely novel consumption practices or patterns of hiring. We develop primary empirical research for the principal case study that determines that the proficiencies of crowd-based capitalism make possible an economy that depends gradually on peer-to-peer platforms to regulate economic operations. We use meta-analysis to inspect evidence proving that rising blockchain technologies might reshape crowd-based capitalism, repositioning the crowd from being the origin of delivery to being the go-between that organizes and jointly dominates the market, but they may drive a novel phase of peer-topeer markets and digital disorder. We attempt to address these increasing aspects by elaborating on the aspect that the variety of conducts and organizations that constitutes the sharing economy is a preceding illustration of a time to come in which peer-to-peer network becomes progressively predominant, and the crowd substitutes the company at the heart of capitalism.
\end{abstract}

Keywords: digital, sharing, economy, sustainable, consumption

JEL Classification: G18, H11, I28

\section{Introduction}

Following Sundararajan (2016), this paper aims to prove that the sharing economy is the present stage of a constant progress of the economy and society that is influenced to some extent by digital technologies. The latter take individuals back to recognizable sharing conducts, selfemployment, and types of community-based network that survived before now (Androniceanu, 2017): an enhanced type of something recognizable should gain boundless acceptance swiftly and have superior economic consequence (Tulloch, 2016) than the creation of completely novel consumption practices or patterns of hiring. (Sundararajan, 2016)

The on-demand economy designates digital media companies (Banning, 2016) that link users via two-sided platform-oriented marketplaces. The most important of on-demand platforms (Uber, Lyft, and Airbnb) indicate the interconnection and inconsistency between the 
New Media Technologies, Digital Sharing, and the Neoliberal Economy

Authors: Elvira Nica, Loren Taylor

social and economic nature of these companies' platforms. Such corporations have had substantial interfering effect upon current transit, housing (Vasile \& Androniceanu, 2016), and labor markets. (Cockayne, 2016)

\section{Literature review}

Sharing as a discursive configuration is instrumental (Selth, 2016) in the design and effectiveness of economic practice. Although labor may be shaped via specific discursive frames (Besciu \& Androniceanu, 2017), employees may repudiate or objectify them in dynamic and unstable fashions that may not accurately display their personal features (Bathelt \& Turi, 2011). The pervasiveness and reproducibility of distributed information online (Belk, 2014), the unimportant value of the latter (Sanz, 2017), and the alleged selflessness of contribution (Williams, 2017) are essential to the economic arrangement of digital systems. Information distributed on social media by separate users has practically no value, an aspect linked to its disproportionate, omnipresent, and effortlessly reproducible traits (Dolack, 2017; McDonald et al., 2017). Transactional platforms (e.g. Airbnb and Uber) tip off the ones that make accessible redundancy of user resources or assets (Jones, 2017; Stinson, 2017). Uber operates on a pattern that hires users as contractors that enables them to deal in their working capacity to other smartphone users. Airbnb users benefit from listing properties, but are not officially hired or paid by the platform. Sharing links a series of distinct economic routines and digital platforms (Androniceanu \& Drăgulănescu, 2016, A), and the laboring subjectivities (Panova \& BuberEnnser, 2016) and affective propensities (Friedman et al., 2016) that are associated with them. Proponents of the on-demand economy advocate or deter, via the preservation of the sharing trope, certain laboring and social routines. (Cockayne, 2016)

\section{Methodology}

Using primary empirical research and meta-analysis we elaborate on the aspect that the variety of conducts and organizations that constitutes the sharing economy is a preceding illustration of a time to come in which peer-to-peer network becomes progressively predominant (Lucas, 2016), and the crowd substitutes the company at the heart of capitalism (Cammaerts, 2011). The adjustability and smoothness of contracting via digital platforms instead of working a day-job (Popescu Ljungholm, 2016) may be challenging (performing on demand for various platforms may be likable), but obtaining a predetermined periodic income (Madsen \& Wu, 2016) assists in organizing a future, something pretty demanding when an individual's earnings vary (Ionescu, 2016) contingent on the caprices of delivery and request on a series of apps. Because other platforms concentrate on service labor increasingly, there is a rising threat of greater future social disparity. (Sundararajan, 2016) Sharing in the on-demand framework aims to regularize flexible kinds of work (Androniceanu, 2014) by postulating labor as a required contribution (Bauder, 2016), a sufficient and roughly ineffective must for inclusion, (Machan, 2016) in which sharing is associated with the recurrence of affect that guarantees social status via economic involvement (Layard, 2016), instead of one on social media platforms. Linking the distribution of information online to sharing in the framework of the on-demand economy takes on amalgamating labor with input of practically useless information. (Cockayne, 2016) 


\section{Empirical data and analysis}

Our estimated data covers what the rise of the sharing economy means for incumbents and types of shared or on-demand online service. We aim to determine that the proficiencies of crowd-based capitalism make possible an economy that depends gradually on peer-to-peer platforms to regulate economic operations. Rising blockchain technologies might reshape crowd-based capitalism (Andrei et al., 2016), repositioning the crowd from being the origin of delivery to being the go-between that organizes and jointly dominates the market, but they may drive a novel phase of peer-to-peer markets and digital disorder. Developing this case, we reflect on the fact that there is a conflict between the profit-stimulated and goal-oriented directions of the sharing economy, between individuals who perceive it as a market economy and people who conceive it as a gift economy. (Sundararajan, 2016) If labor is comprehended in accord with the requirement to distribute information (Siekelova et al., 2017) in the social media frame of reference (Hellman \& Majamäki, 2016), it is underrated and regarded only as a boundlessly accessible product for on-demand investment with almost no monetary worth. Such labor may be considered as real and converted into a superfluous object (Mihăilă, 2016) via conditions established by on-demand companies via the sharing rhetoric and the caprices of smartphone users to invalidate the dissimilarity between digital goods and working capacity. Consumers require conformity from labor no less than they would from goods, and carry out these normative criteria via routines of peer-implemented permissive supervision moderated via the platform. Sharing as a rhetorical figure of speech that guarantees inclusivity in the conditions of the on-demand economy (Weede, 2016) faces a link with the transaction of one's working capacity, and not the contributing of one's ideas on social media platforms. (Cockayne, 2016) (Figures 1-9)

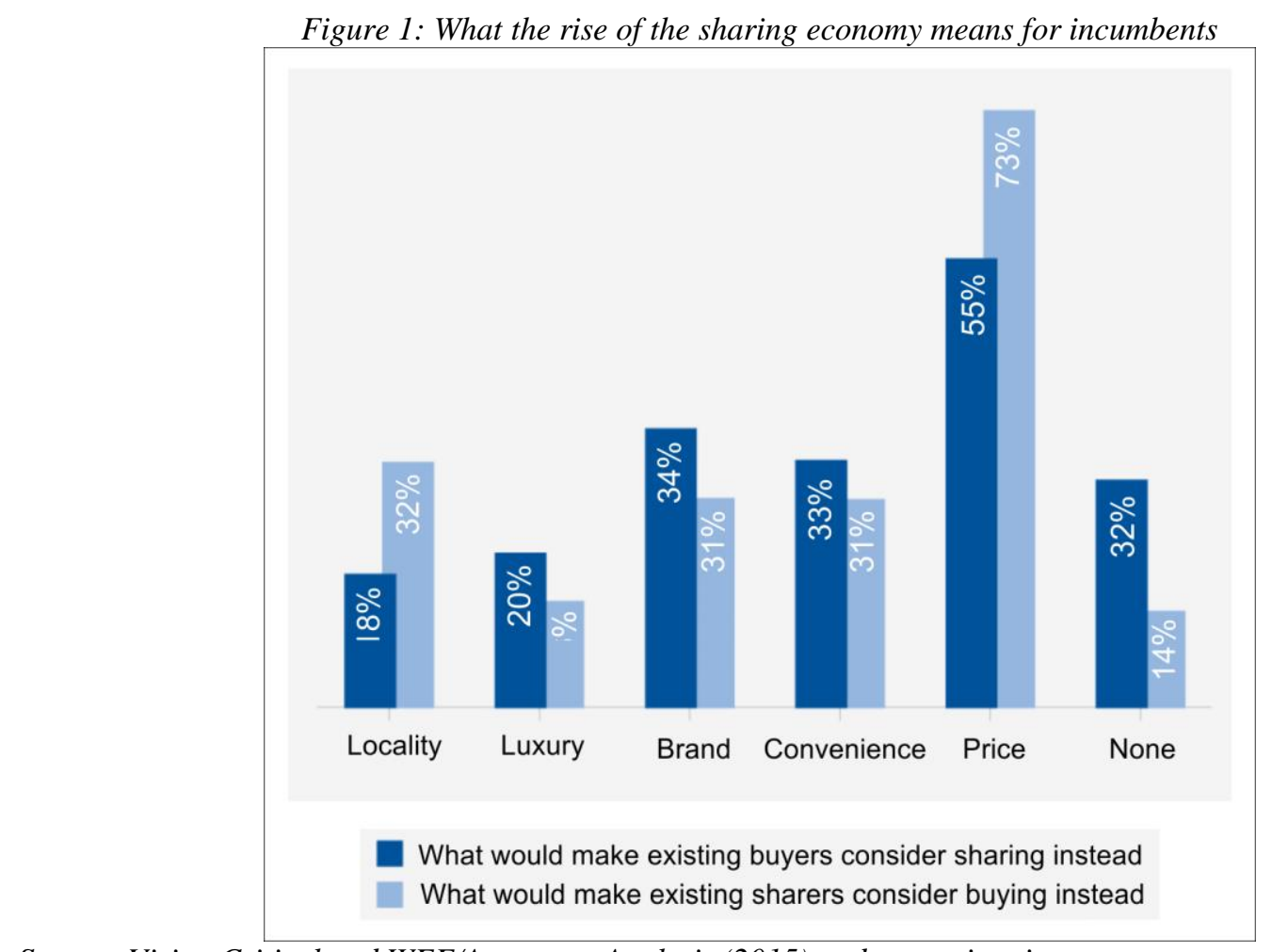

Source: Vision Critical and WEF/Accenture Analysis (2015) and our estimations 
New Media Technologies, Digital Sharing, and the Neoliberal Economy Authors: Elvira Nica, Loren Taylor

Figure 2: LinkedIn ranks the highest in digital trust

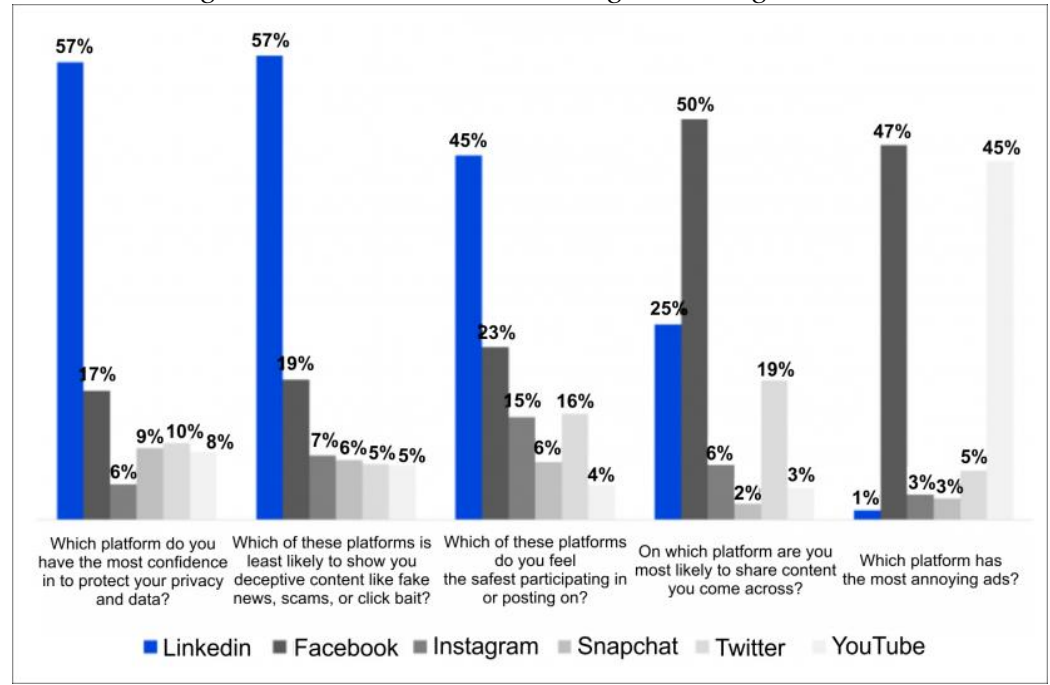

Source: BI Intelligence (2017) and our estimations

Figure 3: The rise of the sharing economy

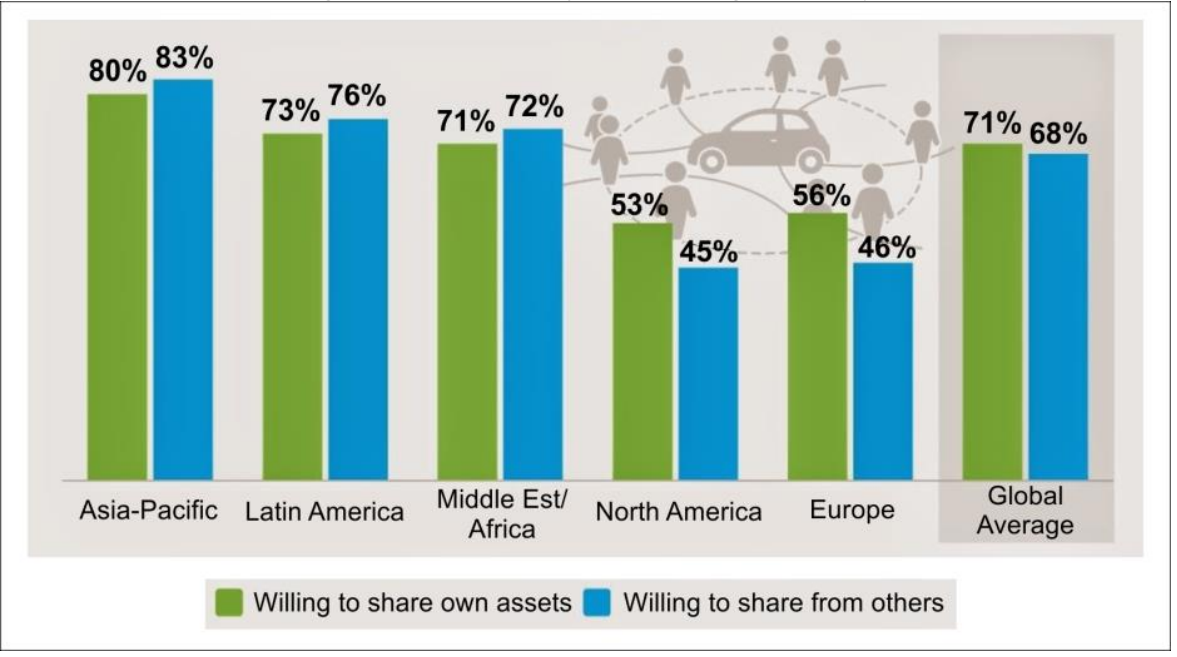

Source: Nielsen, Mashable statista and our estimations

Figure 4: Most commercially important digital marketing trends for 2017

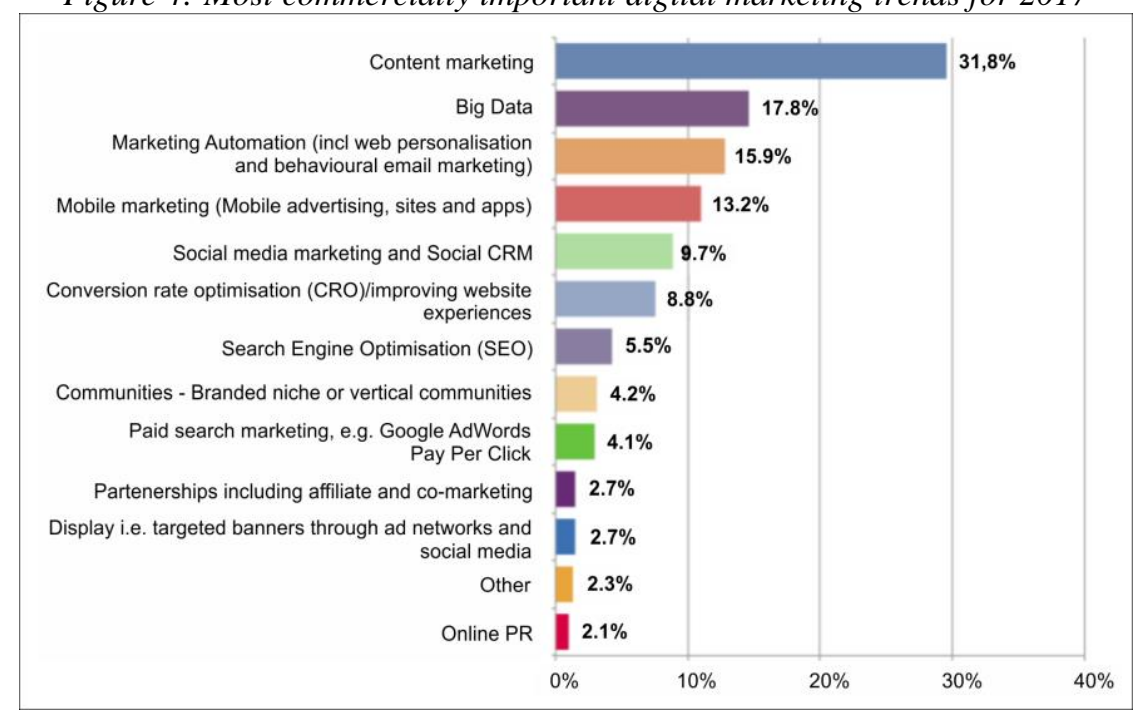

Source: Smart Insights (2015) and our estimations 
Figure 5: Type of shared or on-demand online service

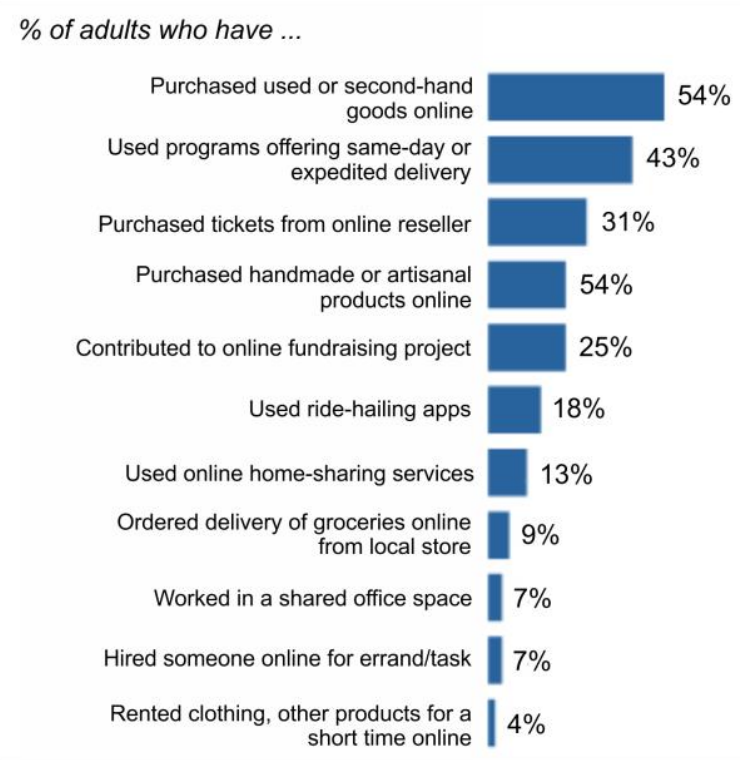

Source: PEW Research Center (2015) and our estimations

Figure 6: Sharing economy and traditional rental sectors (CAGR)

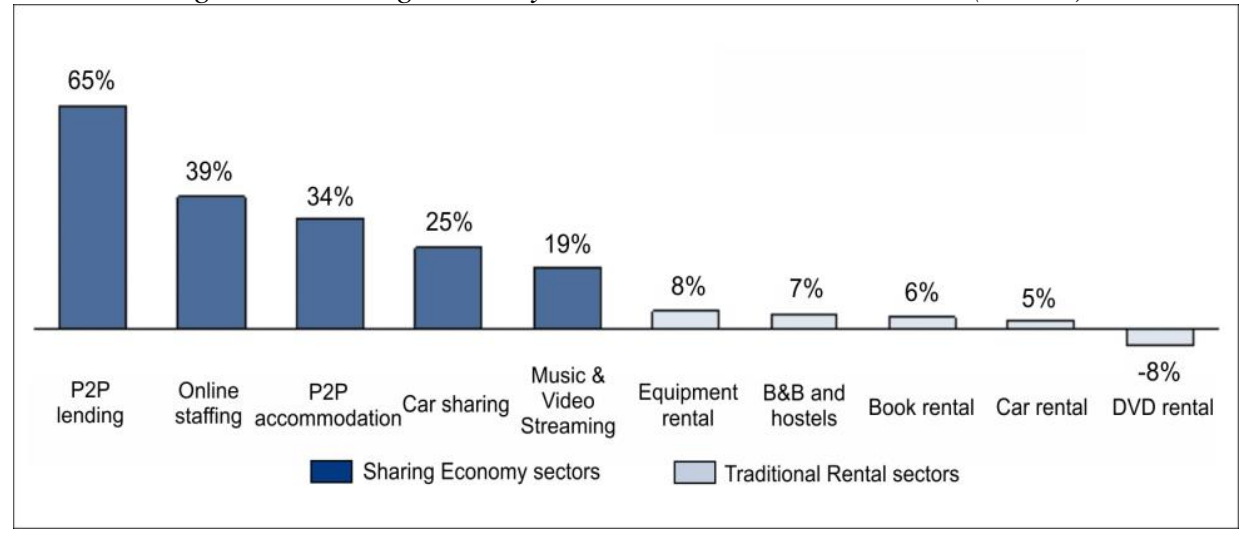

Source: PWC (2013) and our estimations

Figure 7: The rise and fall of agricultural work (farm), industrial work (manuf), knowledge-based and creative work (CC), and routine low-wage service work (LWS) - from 1800 through 2017.

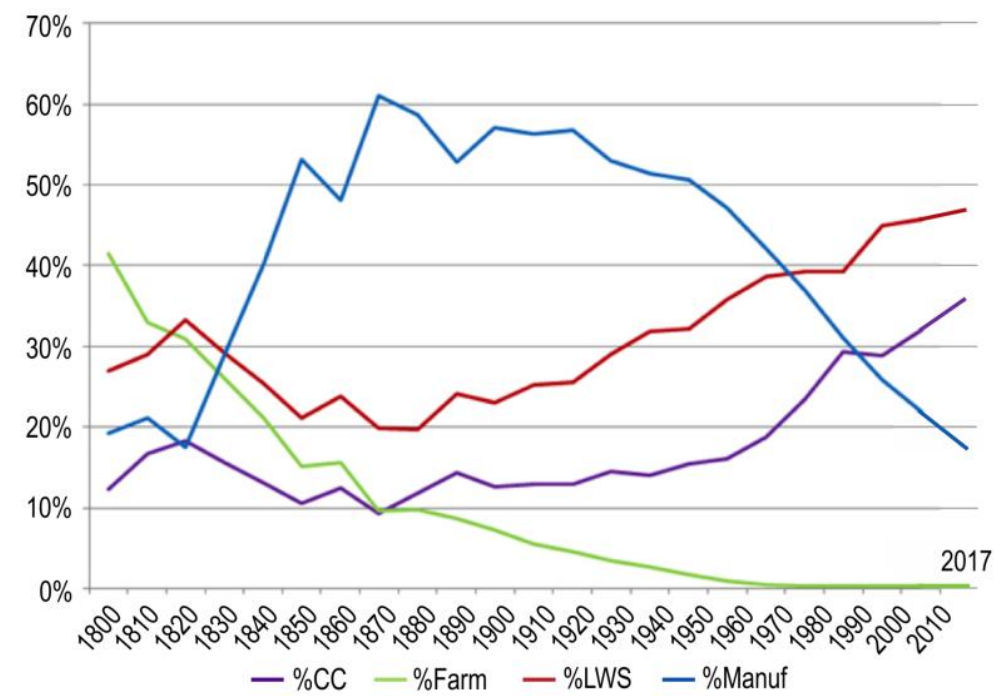

Source: Martin Prosperity Institute and our estimations 
New Media Technologies, Digital Sharing, and the Neoliberal Economy Authors: Elvira Nica, Loren Taylor

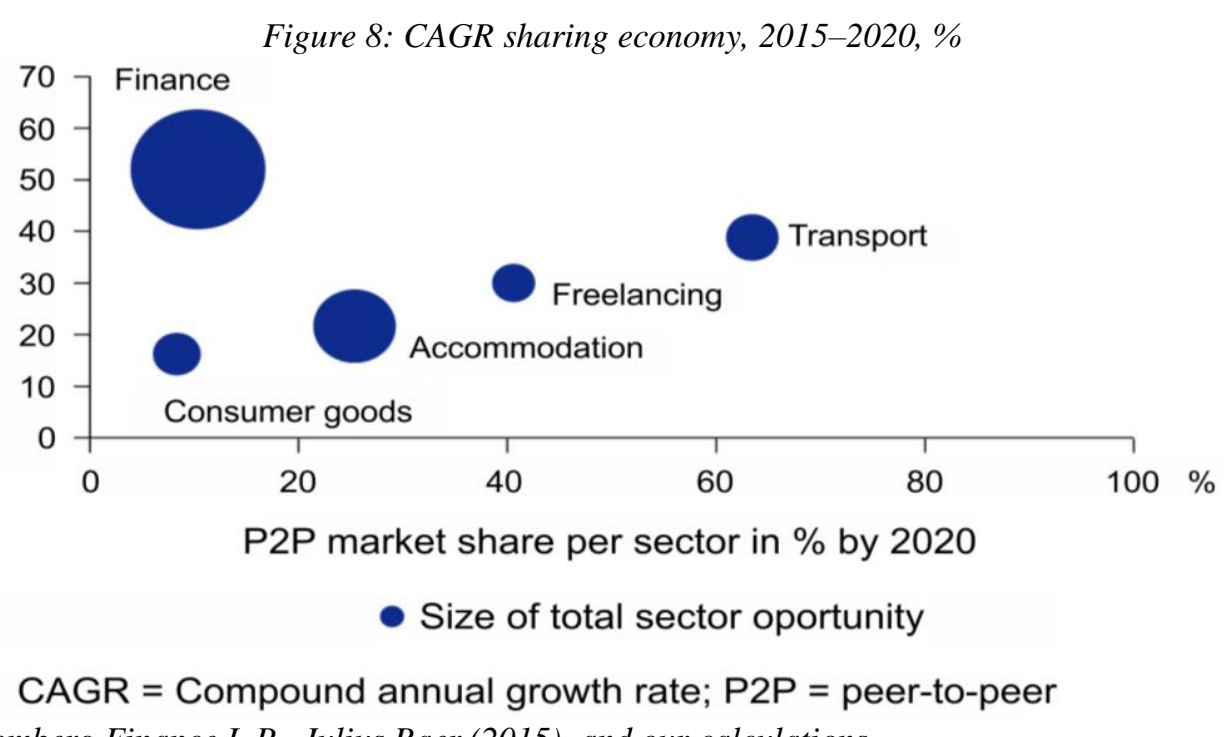

Source: Bloomberg Finance L.P., Julius Baer (2015), and our calculations

Figure 9: U.S. workforce mega-transformations (1790-2017)

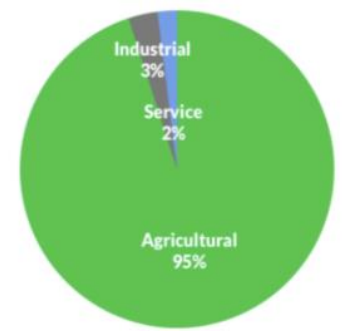

1790

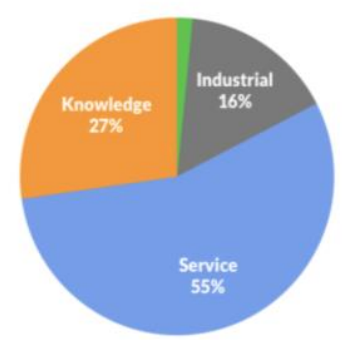

2000

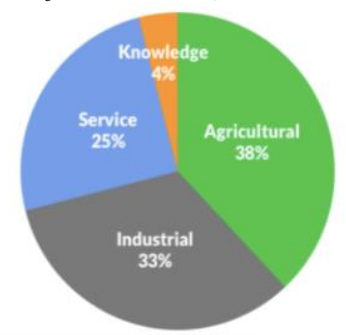

1900

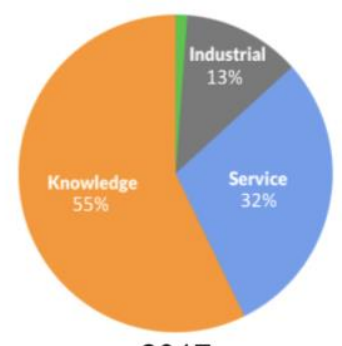

2017

- Agricultural Industrial Service Knowledge

Source: Bureau of Labor Statistics, GSV Asset Management, and our estimations

\section{Results and discussion}

On-demand laborers create, without associating truthfully with, the digitally interposed type of capitalist exchange. The sharing rhetoric hides the commitment of transformation to the capitalist way of production (Hurd, 2016), via a proposal for a more reliable and established kind of primarily social connection that furthers labors' collaboration in the standardization of flexible work. On-demand platforms reinforce a grasp of goods and labor as unceasing, not disparate. The ideology of the sharing rhetoric redefines the notion of labor, while advancing an authentic alteration and concern for another course of action to the capitalist system (Anderson \& Kantarelis, 2016), or a comeback to a relevant series of social connections. Apparent social dissimilarities between classes are eliminated from the public realm (Oliver, 2016), because the capitalist does not come across the laborers at a concrete market to deal in 
their working capacity, operating transactions under conditions established by a third party platform, via the employment of a digital application (Androniceanu \& Drăgulănescu, 2016, B) on a smartphone, besides intensifying the false impression of fairness between capitalist and worker (Williams et al., 2016), who both engage in an interactive delusion that the requirement formulated by the former in relation to the acquisition of the latter's working capacity is a broad and social kind of sharing. (Cockayne, 2016)

\section{Conclusions}

On-demand and various other digital companies and platforms engage in the creation of the sharing rhetoric (Popescu \& Predescu, 2016), which has a decisive role in the on-demand economy. Sharing, as a regulating undertaking for depicting on-demand labor, is a scheme for approaching the latter in idealistic terms of social connections and cooperation in neoliberal capitalism. Labor as something distributed, and not traded and paid for in the on-demand economy, is figurative with a kind of redundant always-accessible data. The workers who decide not to distribute their labor are construed as the characters that ungenerously or defiantly repudiate the commitment of involvement in the novel better existence and community. Sharing sets up the circumstances for debating labor as something users are allowed to access effortlessly and anytime (Androniceanu, 2012): the on-demand economy aims to conceive a series of prerequisites for grasping labor as something nonrefundable that should reciprocate swiftly to the requirements of smartphone users. (Cockayne, 2016)

\section{Note}

A version of this article was previously presented at the $17^{\text {th }}$ International Scientific Conference Globalization and Its Socio-Economic Consequences, University of Zilina, 4-5 October 2017.

\section{References}

Anderson, E. and Kantarelis, D. (2016). Incentive-compatibility and Coasean invariance in property affairs. Contemporary Readings in Law and Social Justice, 8, 96-114.

Androniceanu, A. (2012). Key issues related to the human resources management nowadays. Proceedings of the $6^{\text {th }}$ International Management Conference: Approaches in Organisational Management. Bucharest, Romania, 221-230.

Androniceanu, A. (2014). Research on management capacity of medical units for addicts to deliver quality services in time of crisis. Revista de Cercetare si Interventie Sociala, 47, 78-104.

Androniceanu, A. and Drăgulănescu, I.V. (2016, A). A survey on the buyers' eco-responsibility and the urban white pollution. Environmental Engineering and Management Journal, 15, 481-487.

Androniceanu, A. and Drăgulănescu, I.V. (2016, B). Sustainability of the organizational changes in the context of global economic crisis. Amfiteatru Economic, 14, 365-379.

Andrei, A., Galupa, A., Androniceanu, A. and Georgescu, I.A. (2016). Monetary policy with constant real stock of bonds. Economic Computation and Economic Cybernetics Studies and Research, 50, 101-116.

Androniceanu, A. (2017). The three-dimensional approach of total quality management, an essential strategic option for business excellence. Amfiteatru Economic, 19, 61-78.

Banning, M.E. (2016). Shared entanglements - Web 2.0, info-liberalism \& digital sharing. Information Communication \& Society, 19(4), 489-503.

Bathelt, H. and Turi, P. (2011). Local, global and virtual buzz: The importance of face-to-face contact in economic interaction and possibilities to go beyond. Geoforum, 42(5), 520-529.

Bauder, H. (2016). Understanding Europe's refugee crisis: A dialectical approach. Geopolitics, History, and International Relations, 8, 64-75.

Belk, R. (2014). You are what you can access: Sharing and collaborative consumption online. Journal of Business Research, 67(8), 1595-1600. 
New Media Technologies, Digital Sharing,

and the Neoliberal Economy

Authors: Elvira Nica, Loren Taylor

Besciu, C.D. and Androniceanu, A. (2017). The link between social inequalities, health system characteristics and R\&D expenditure - worldwide evidence. Romanian Statistical Review, 2, 21-41.

Cammaerts, B. (2011). Disruptive sharing in a digital age: Rejecting neoliberalism? Continuum-Journal of Media \& Cultural Studies, 25(1), 47-62.

Cockayne, D.G. (2016). Sharing and neoliberal discourse: The economic function of sharing in the digital ondemand economy. Geoforum, 77, 73-82.

Dolack, P. (2017). Cooperatives confront capitalism: Challenging the neoliberal economy. Journal of Labor and Society, 20(1), 149-152.

Friedman, D., Friedman, H.H. and Friedman, L.W. (2016). US healthcare: A system in need of a cure. American Journal of Medical Research, 3, 125-141.

Hellman, M. and Majamäki, M. (2016). Ordinary men with extra-ordinary skills? Masculinity constructs among MMORPG-gamers. Journal of Research in Gender Studies, 6, 90-106.

Hurd, H.M. (2016). The innocence of negligence. Contemporary Readings in Law and Social Justice, 8, 48-95.

Ionescu, L. (2016). Mechanisms for enhancing ethical behavior in the accounting profession. Contemporary Readings in Law and Social Justice, 8, 263-269.

Jones, B. (2017). Neoliberal moral economy: Capitalism, socio-cultural change and fraud in Uganda. European Journal of Development Research, 29(5), 1122-1124.

Layard, R. (2016). Why we should spend more on mental health. American Journal of Medical Research, 3, 188206.

Lucas, R.E.B. (2016). Integral migration in developing economies: An overview of recent evidence. Geopolitics, History, and International Relations, 8, 159-191.

Machan, T.R. (2016). The morality of gregarious egoism. Contemporary Readings in Law and Social Justice, 8 , 7-29.

Madsen, E.S. and Wu, Y. (2016). Low R\&D efficiency in large pharmaceutical companies. American Journal of Medical Research, 3, 141-151.

McDonald, M., Gough, B., Wearing, S. and Deville, A. (2017). Social psychology, consumer culture and neoliberal political economy. Journal for the Theory of Social Behaviour, 47(3), 363-379.

Mihăilă, R. (2016). Is the decrease in the gender wage gap the principal driver of the sustained rise in female labor market participation? Journal of Research in Gender Studies, 6, 146-152.

Oliver, T. (2016). Goodbye Britannia? The international implications of Britain's vote to leave the EU. Geopolitics, History, and International Relations, 8, 214-233.

Panova, R. and Buber-Ennser, I. (2016). Attitudes towards parental employment: A ranking across Europe, Australia, and Japan. Journal of Research in Gender Studies, 6, 11-37.

Popescu, G.H. and Predescu, V. (2016). The role of leadership in public health. American Journal of Medical Research, 3, 273-279.

Popescu Ljungholm, D. (2016). The role of work organizations in the social construction of gender. Journal of Research in Gender Studies, 6, 269-275.

Sanz, M.D. (2017). The international state of corporate social responsibility: Actors and disputes in the context of the globalized neoliberal economy. Empiria, 37, 191-195.

Selth, A. (2016). The road to Mandalay: Orientalism, 'Burma girls' and Western music. Journal of Research in Gender Studies, 6, 159-191.

Siekelova, A., Kliestik, T., Svabova, L., Androniceanu, A. and Schonfeld, J. (2017). Receivables management: The importance of financial indicators in assessing the creditworthiness. Polish Journal of Management Studies, 15, 217-228.

Stinson, J. (2017). Re-creating Wilderness 2.0: Or getting back to work in a virtual nature. Geoforum, 79, 174187.

Sundararajan, A. (2016). The sharing economy: The end of employment and the rise of crowd-based capitalism. Cambridge, MA, and London: The MIT Press.

Tulloch, L. (2016). The transnational state, neoliberalism and environmental education policy: A New Zealand case study. Contemporary Readings in Law and Social Justice, 8, 170-195.

Vasile, O. and Androniceanu, A. (2016). Dynamics of migration in Romania and management of financing instruments. European Proceedings of Social and Behavioural Sciences. Iasi, Romania, 1059-1067.

Weede, E. (2016). Geopolitics, institutions, and economics: On the rise and decline of civilizations. Geopolitics, History, and International Relations, 8, 177-220.

Williams, C.C. (2017). Tackling employment in the informal economy: A critical evaluation of the neoliberal policy approach. Economic and Industrial Democracy, 38(1), 145-169.

Williams, J.C., Phillips, K.W. and Hall, E.V. (2016). Tools for change: Boosting the retention of women in the STEM pipeline. Journal of Research in Gender Studies, 6, 11-75. 